\title{
An Analytical Study on Anemia in Rural Population
}

\author{
Shirish Ardhapuskar ${ }^{\circledR 1}$, Raghu Rammulu ${ }^{\circledR 2}$ \\ ${ }^{1}$ Professor, Department of General Medicine, GEMS Medical College, Srikakulam, Ragolu, Andhra Pradesh, India, ${ }^{2}$ Assistant Professor, Department of General Medicine, \\ SVS Medical College, Mahabub Nagar, Telangana, India.
}

\section{Abstract}

Background: Anemia is one of the common Hematological disorders in India and worldwide. It affects all the age groups both in Males and Females. Moderate to Severe Anemia causes increased morbidity and mortality in elderly patients (AWHO expert group) - According to Worlds Health Organization, Anemia is a define when adults males are having Hemoglobin less than 13.5gr\% when adults females non-pregnant less than $12 \mathrm{gr} \%$ and when pregnant females are having less than $11 \mathrm{ger} \%$. The incidence of Anemia is very high in old age people who are more than 75 years of age. It ranges from $9 \%$ to $41 \%$. In India Anemia is commonly due to nutrition, pregnancy, Hookworm infestation, DUB in the case of females, and Malignancy. The prevalence of anemia in the elderly has been found to range from $9 \%$ to $42 \%$ with the highest prevalence in 80 years and above. The common causes of anemia in India are Nutritional, Pregnancy, Hookworm infestation, and DUB in the case of Females and Malignancy. The common symptom is General weakness, Fatigue, Lack of concentration, Shortness of Breath, and Palpitations. A WHO expert group proposed that anemia should be considered when hemoglobin level below $13.5 \mathrm{gr} \&$ in adult males; $12 \mathrm{gr} \%$ in adults females non-pregnant; $11 \mathrm{gr} \%$ in adult female pregnant; $12 \mathrm{gr} \%$ in children over $14 \mathrm{yrs}(1)$. The aim is to evaluate the etiology and clinical features of anemia in adults in rural medical colleges. Subjects \& Methods: This study is conducted at GEMS Medical College, Srikakulam, A.P for the period of 1 year from April 2018 to March 2019. This study includes 120 patients with Anemia. The age group is between 20 years and 70 years. Males were 56 and females were 64. Results: We have conducted this study at GEMS Medical College, Srikakulam for 1 year, from April 2019 to March 2019 total no. of patients included in this study are 120 males 56 and females 64 . The age group is between 20 years and 70 years. The maximum patients are in between 30 years and 70 years in both sexes. Conclusion: Anemia is a common medical problem in developing countries. In a rural part of India, the disorders will complicate the pregnancy also. So periodical examination and education of the people can decrease morbidity and mortality. In our area still, the common cause is nutritional.

Keywords: Anemia, Hemoglobin, Iron deficiency, Leukemia, Bleeding disorders

Corresponding Author: Raghu Rammulu, Assistant Professor, Department of General Medicine, SVS Medical College, Mahabub Nagar, Telangana, India.

E-mail: drraghuananthoju@gmail.com

Received: 19 August 2020

Revised: 01 October 2020

Accepted: 12 October 2020

Published: 26 December 2020

\section{Introduction}

Anemia is a common hematological problem in developing countries India Srilanka, Bangladesh, and African countries like According to WHO definition Anemia is a decreasing carrying capacity of Hemoglobin. ${ }^{[1]}$ A WHO expert group proposed that anemia should be considered. When Hemoglobin levels below $13.5 \mathrm{gr} \%$ in adult males; $12 \mathrm{gr} / \mathrm{dl}$ in adult females no pregnant; $11 \mathrm{gr} \%$ in adult females pregnant: $12 \mathrm{gr} \%$ in children over 14years. It affects all age groups and both sexes. The prevalence of anemia is high in the elderly population from 12 to $42 \%$ the highest is in the $7^{\text {th }}$ and $8^{\text {th }}$ decade. ${ }^{[2]}$ Classification of anemias is divided as Pathological and morphological. Pathological classification is 2 types (i) due to decreased $\mathrm{RBC}$ eg. Iron deficiency Thallasemias, (ii) is increased RBC destruction e.g. hemolytic anemia. Morphologically depends on RBC size (i) Microcytic (ii) Macrocytic (Megaloblastic) (iii) normocytic examples of microcytic anemia's are (i) Iron deficiency (ii) Thalassemia's (iii) Anemias of chronic disease. Macrocytic anemia is seen due to Vit $\mathrm{B}_{12}$ and Folic acid deficiency. ${ }^{[3]}$ Formed elements of Blood are produced by the process called hematopoiesis, Erythropoietin (EPO) is the primary regulatory hormone for Red cell production. Erythropoietin is produced and released by per-tubular capillary lining cells of the kidney. ${ }^{[4]}$ The common causes of iron deficiency Anemia are nutritional gastrointestinal bleeding (including Bleeding peptic ulcers and hemorrhoids) and CRF. Hookworm infestations and other infections, pregnancy, and Malignaies, Megaloblastic Anomalies is caused by pregnancy, Vit - B12 and Folic acid deficiency, alcoholism, cir- 
rhosis of the liver and hemolytic anemias are caused by blood loss, Metabolic defects, Membrane abnormalities, and hemoglobinopathies. ${ }^{[5]}$ The common symptoms include General Weakness easy tiredness, Breathlessness, Lack of Concentration, Palpitations and signs include paler, tachycardia, high volume pulse. Wide pulse pressure and sometimes Murmurs may hear lymphadenopathy and signs of bleeding tendencies may also be seen. In megaloblastic anemia, sensory symptoms may present. ${ }^{[6]}$ Iron is not only an important element in hemoglobin but also other essential elements in the body. Myoglobin, cytochromes, cytochromes oxidase are. The total quality of iron in the body averages $4000 \mathrm{mg}$ to 5 grams about $65 \%$ of which is in the form of hemoglobin; about $4 \%$ is in the form of Myoglobin. In the cell cytoplasm, Iron combines mainly with a protein apoferritin to form Ferritin. ${ }^{[7]}$ Iron is absorbed from all parts of the small intestine, in the form of apo transferrin and transferrin. Anemia is a reduction in the member of a red cell of hemoglobin in the blood that can reflect the impaired synthesis of hemoglobin (eg in iron deficiency); or impaired production of erythrocytes (eg: folic acid, Vit $\mathrm{B}_{12}$ deficiency). ${ }^{[8]}$ Three stages of Iron deficiency have been described 1) the first stage characterized by decreased storage of iron without any other delectable abnormalities 2) the Second stage and intermediate stage of latent iron deficiency 3 ) the Third stage, overt iron deficiency when there is a decrease in the concentration of circulating hemoglobin due to impaired hemoglobin synthesis. ${ }^{[9]}$ Iron is mostly absorbed from the duodenum and small intestine the Factors which decrease absorption of iron are phosphates, a decrease of Jejunum and duodenum. Ascorbic acid increases the absorption of iron. There are different types of chains are designated alpha chains, beta chains, gamma chains, and delta chains. The most important form of hemoglobin in the adult human being $\mathrm{A}$ is a combination of 2 alpha chains, 2 beta chains.

\section{Subjects and Methods}

We have conducted this study for 1 year from April 2018 to March 2019 in GEM Medical College. AP 120 patients were included in this study. Among the 12056 were males 64 are females. The age group included is between 20 years 70 years, Maximum no. of patients are in between 50 years and 70 years. After are fully taking the history and clinical examination we have send the blood samples for total count \& differential count $\mathrm{Hb} \%$, Random blood sugar Serum Keratinize blood urea, LFT, Serum Ferrites, Vit $\mathrm{B}_{12}$ \& Folic acid estimation, and bone mass and peripheral smear examination. Stool for ora \& cyst is also done. We have informed and obtained consent from patients and obtained college ethical committee approval also. Ultrasound abdomen examination and upper GI endoscopy colonoscopy were done in suspected cases. Coombs test is also done.
The data was computerized and analyzed. Systematically using MS. Office.

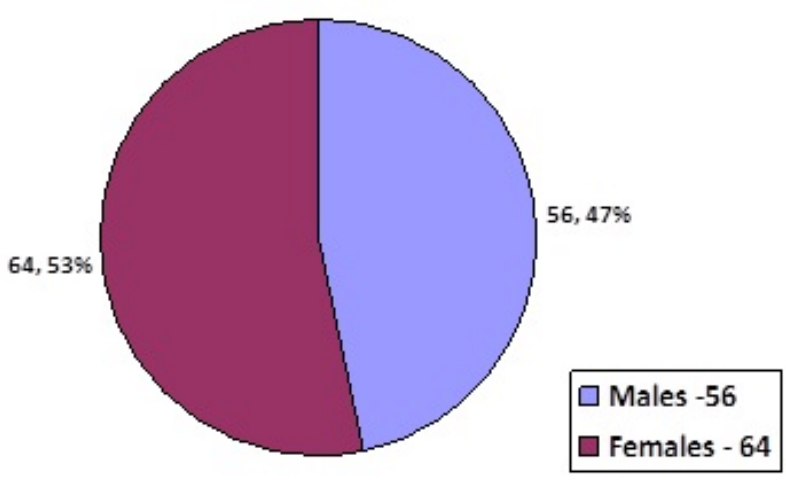

Chart 1: Sex Wise Distribution
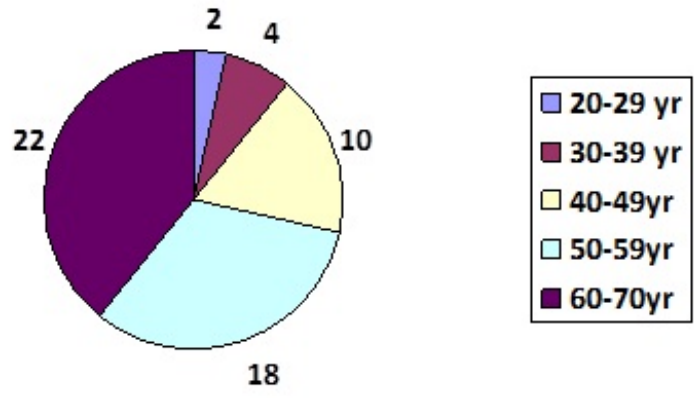

Chart 2: Age-Wise Distribution in Males

The symptoms in orders of frequency are General weakness Fatigue. Shortness of Breath, palpitations, and syncope. The most important signs are pallor, tachycardia, Angular steatites, bounding pulse koilonychia, and lymphadenopathy.

\section{Results}

We have examined 120 patients; Males were 56 and Females 64. The common age group is between 20 years and 70 years. In males in the $50-60$ years age group. 18 patients (32.14\%) are $60-70$ years. 22 patients $(39.28 \%)$ whereas in females in $50-60$ years age group 19 patients $(29.68 \%)$ and in $60-70$ years age group 25 patients $(38.06 \%)$.

The most common symptoms are general weakness and fatigue is seen in 23 male's patients and 20 female's patients. 


\begin{tabular}{|c|c|c|c|c|}
\hline Age in years & Males 54 no. of patients & Percentage & Female 64 no. of patients & Percentage \\
\hline $20-29 \mathrm{yr}$ & 2 & $3.77 \%$ & 3 & $4.68 \%$ \\
\hline $30-39 \mathrm{yr}$ & 4 & $7.14 \%$ & 5 & $7.81 \%$ \\
\hline $49-49 \mathrm{yr}$ & 10 & $17,85 \%$ & 12 & $18.75 \%$ \\
\hline $59-59 \mathrm{yr}$ & 18 & $32.14 \%$ & 19 & $29.68 \%$ \\
\hline $60-70 \mathrm{yr}$ & 22 & $39.28 \%$ & 25 & $38.06 \%$ \\
\hline
\end{tabular}
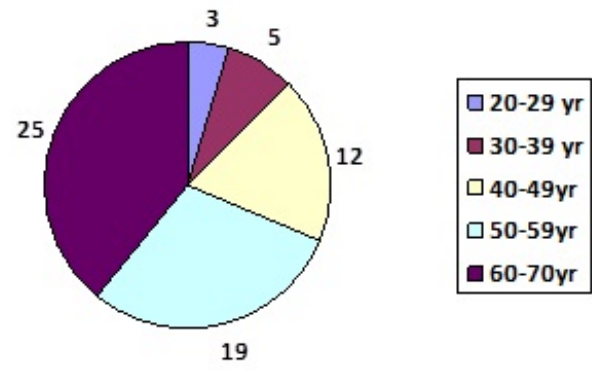

Chart 3: Age-Wise Distribution in Females

\begin{tabular}{lll}
\hline \multicolumn{3}{l}{ Table 2: Symptoms in Males and Females } \\
\hline Symptoms & $\begin{array}{l}\text { Males } \\
\text { Patients } \\
\mathbf{5 6}\end{array}$ & $\begin{array}{l}\text { Female } \\
\text { Patients } \\
\mathbf{( 6 4 )}\end{array}$ \\
$\begin{array}{l}\text { General weakness } \\
\text { fatigue }\end{array}$ & $23(41.15 \%)$ & $20(31.25 \%)$ \\
Breathlessness & $6(10.71 \%)$ & $8(12.55 \%)$ \\
\hline $\begin{array}{l}\text { Palpitations } \\
\text { Syn cope }\end{array}$ & $6(10.71 \%)$ & $9(7.81 \%)$ \\
Parasthesias & $4(7.14 \%)$ & $5(7.71 \%)$ \\
\hline & $2(3.57 \%)$ & $2(3.12 \%)$ \\
\hline
\end{tabular}

Table 3: Haemoglobin levels.

\begin{tabular}{lll}
\hline Hb\% Levels & Males & Females \\
$11-9$ gr. dl & 20 & 36 \\
$9-6 \mathrm{gr} / \mathrm{dl}$ & 25 & 22 \\
$6 \mathrm{gr} / \mathrm{dl}$ & 9 & 6 \\
\hline
\end{tabular}

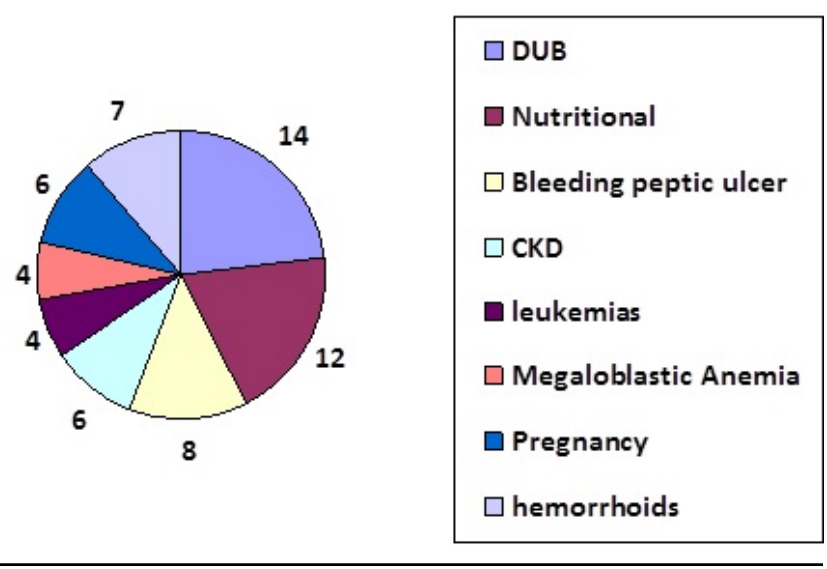

Chart 4: Hemoglobin Levels
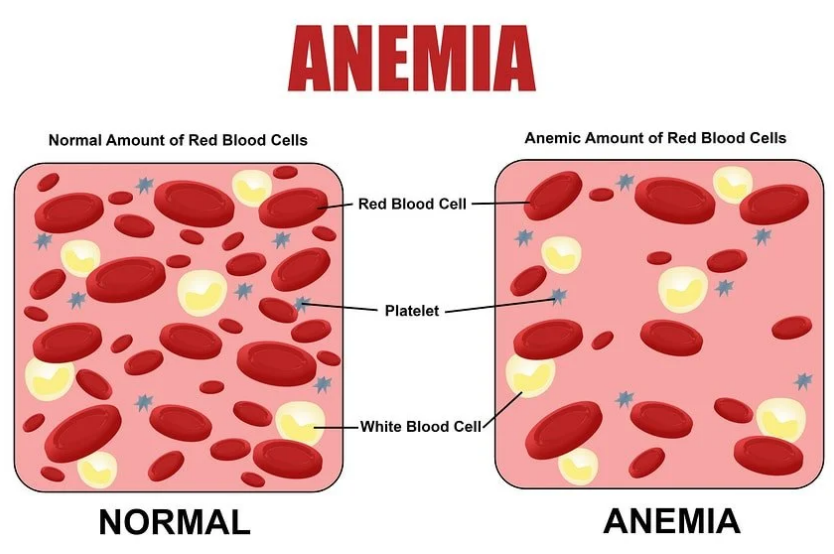

Figure 1: Iron Deficiency Anemia

Breathlessness and palpitations are seen in 6 male patients and 8 females' patients. More than $50 \%$ of patients both male and female are having mild anemia according to $\mathrm{Hb} \%$ LEVELS (11-9 gr/dl) and about 30\% are having moderate anemia $(\mathrm{Hb} \%$ 9-6 gr/dl) and $<5 \%$ are having severe or gross anemia $(\mathrm{Hb} \%$ is $<6 \mathrm{gr} / \mathrm{dl}$ ). The most common cause of anemia in this study is iron deficiency anemia, next is Megaloblastic Anemia and last is Hemolytic Anemia (78\% are having iron deficiency Anemia 18\% are having Megaloblastic Anemia and 4\% are 


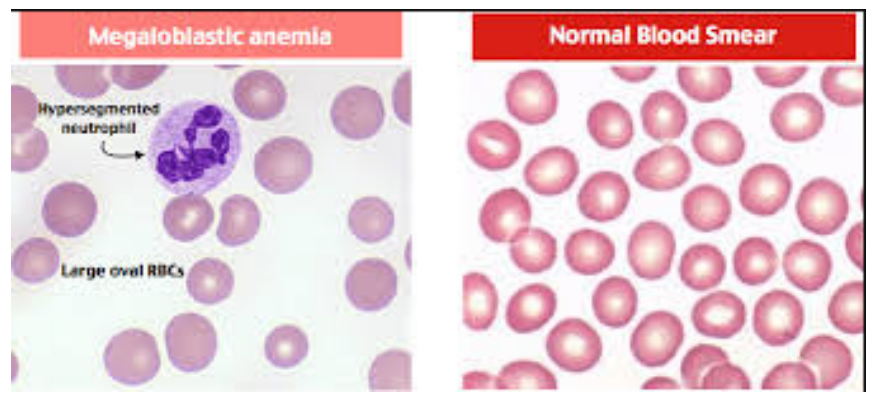

\section{Figure 2: Megaloblastic Anemia}

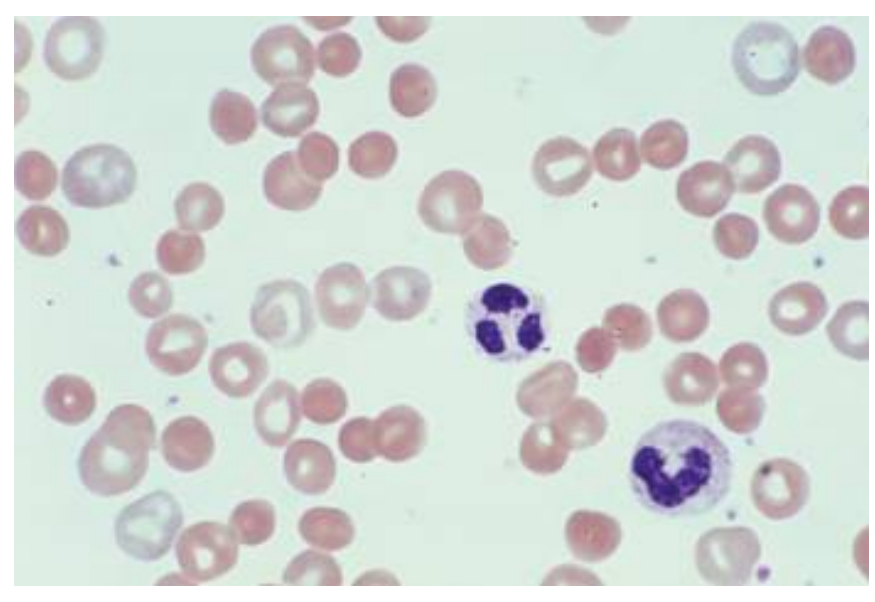

Figure 3: Hemolytic Anemia

having hemolytic Anemia).

\section{Discussion}

Anemia is a very common problem. Especially in old age, the prevalence of Anemia is increase as age is increasing to $7^{\text {th }}$ decade and $8^{\text {th }}$ decades, in our study in the $7^{\text {th }}$ decade $39.28 \%$ in males and $38.06 \%$ in Females. ${ }^{10]}$ Tettamanti M et al conducted a study on prevalence. It shows $46.5 \%$ prevalence in elderly people. Anemia is classified according to the pathophysiologic basic, whether related to increased production (reticulocytosis) or decreased production (reticulocytopenia) and according to RBC size. Reticuloytosis occurs in one of three pathophysiologic states; 1) acute blood loss 2) recent replacement of erythropoietic nutrients 3 ) hemolysis. ${ }^{[1]}$

The common causes of Anemia are nutritional, bleeding peptic ulcer, Hemorrhoids, and Menorrhagia, and DUB in Females Megaloblastic anemia is seen in pregnant women and Males above 50 years. In Megalobasltic anemia due to Vit $\mathrm{B}_{12}$ Deficiency, the majority of patients are vegetarians. In Females the causes multifactorial like pregnancy, menorrhagia, and carci- noma calcium, social and economic.

A study conducted by Govt. of India in 1978 shows that Nutrition and pregnancy are more common causes of Anemia in women. ${ }^{[12]}$ In Males, the more common causes are Bleeding peptic ulcer, and Hemorrhoids causes of Anemia in the elderly are broadly classified into 3 types (1) Nutritional (2) Anemia of chronic disease, and (3) unexplained Anemia.

Drugs also can cause Anemia the Mechanism is unknown \& may be suppression of erythropoiesis and other co-morbid conditions leads to Anemia due to drugs. Vitamin B12 absorption may be decreased by oral Hypoglyucemic drugs like Metformin and antiepileptics like phenytoin.

According to a study conducted by Douglass et al the causes of Anemia in old age, people are (1)Anemia of chronic disease $35-42 \%$ iron deficiency Anemai 18-22\% and Megaloblastic anemia is $7-9 \%$. Iron cannot be absorbed from the Jejunum and duodenum in chronic blood loss. The surge of RBC is decreased to give rise to the Microcytic and Hypochronmic type of anemia. In megaloblastic Anemia, RBCS are increased in size distorted in shape, with low fragility membrane which ruptures easily. In Hemolytic Anemia, The RBCs may have normal size but life span in short. In hereditary spherocytosis the RBCs are small in size and spherical in shape, the biconcave disease is not seen. The abnormal hemoglobin $\mathrm{S}$ is present in sickle cell Anemia 0.5 to $1.0 \%$ of west African are having hemolytic Anemia.

Upper Gastrointestinal lesions are more common than lower gastrointestinal lesions, peptic ulcer disease alcoholic gastritis, and drug-induced gastritis due to NSAIDS, which are very common, According to a study conducted by Lucas CA; Logan EC shows similar results. ${ }^{[13]}$ In a study conducted by Dougless et al, the most common cause of Anemia in the elderly was anemia of chronic disease $(30-40 \%)$, iron deficiency anemia is $15-20 \%$ Vit $\mathrm{B}_{12}$ deficiency is 5 $10 \%$. Red cells that are much smaller than normal and have too little hemoglobin inside them are then produced giving rise to Microcytic, Hypochromic anemia. ${ }^{[14]}$ In Megaloblastic Anemia, erythroblasts cannot proliferate rapidly enough to form a normal number of Red cells, those Red cells that are formed are mostly increases in size and different shapes, and have fragile membranes, these cells rupture easily, leaving the person in dire need of an adequate number of red cells. In Hemolytic anemia, the number of Red cells formed may be normal but the life span of fragile red cells is short. In hereditary spherocytosis, the red cells are very small and spherical rather than biconcave discs. In sickle cell anemia, which is present in 0.3 to $1.0 \%$ of West African and American blocks, the cells have an abnormal type of hemoglobin called hemoglobin S; containing faulty beta chain is the hemoglobin molecule. The presence of Fever is significant in Anemia; infection may be the common cause. The Natural defense mechanism by which neutrophils 
and macrophages will be decreased. Normally the bacteria will be killed and ingested by neutrophils and Macrophages. The important cause of cytopenia is Megaloblastic Anemia Thrombocytopenia usually develops when the severity of Anemia increases. ${ }^{[15]}$ In megaloblastic Anemia, erythroblasts cannot proliferate rapidly and $\mathrm{RBC}$ which are formed are increased in size and with a distorted shape with low Fragility of Membrane. In hemolytic Anemia the number of RBCs is normal but the life span will be decreased. The most important index in serum iron concentration less than 0.50 $\mathrm{mg}$ / indicates iron Deficiency. The single most investigation is serum ferritin levels. Iron stores in the body are reflected by serum ferritin levels less than 10 micro indicates the absence of iron stores. Serum transferrin saturation should be above $16 \%{ }^{[16]}$ Iron absorption is increased by vitamin $\mathrm{C}$, fructose, and ethanol. Vitamin B12 is found in foods of animal origin. This means strict vegetarians are at risk of developing Vitamin B 12 deficiency. ${ }^{[17]}$ Megaloblastic anemia is an important cause of cytopenia, but to the best of our knowledge, there are not many studies quoting its incidence. It is generally believed that as the severity of anemia increases, thrombocytopenia develops followed by. ${ }^{[18]}$ In Megaloblastic Anemia, erythroblasts cannot proliferate rapidly enough to form a normal number of Red cells, those Red cells that are formed are mostly oversized, have bizarre shapes, and have fragile membranes, these cells rupture easily, leaving the persons in dire need of an adequate number of red cells, In Hemolytic anemia, the number of Red cells formed may be normal but the life span of fragile red cells are short. In hereditary spherocytosis, the red cells are very small and spherical rather than Bi concave dishes. In sickle cell anemia, which is present in 0.3 to $1,0 \%$ of West African and American blocks, the cells 1 have an abnormal type of hemoglobin called hemoglobin $\mathrm{S}$, containing faulty beta chain in the hemoglobin molecule. ${ }^{[19]}$ In megaloblastic anemia, peripheral smear shows macrocytosis, anisopoikilo cytosis in $97 \%$ cases and hyper segmental neutrophils shows $88 \%$. Prabha et al. found similar results in their study. The studies conducted by Subrahmanyam shows $57.35 \%$ of hyper segmented neutrophil in megaloblastic anemia. Vitamin $B_{12}$ is found only in foods of animal origin although it is synthesized exclusively by microorganisms there is being no plant source of this vitamin. This means the strict negations are at risk of developing vitamin $\mathrm{B}_{12}$ deficiency. ${ }^{[20]}$ Vitamin $\mathrm{B}_{12}$ is absorbed bound to intrinsic factor, a small glycoprotein secreted by parietal cells of the gastric mucosa. Gastric acid and pepsin release the vitamin from protein binding in food and make it available to bind to cobalophinlin. Previous anemia arises when vitamin $\mathrm{B}_{12}$ deficiency blocks the metabolism of folic acid leading to functional folate deficiency. The common causes are Iron deficiency and vitamin $\mathrm{B}_{12}$ and folic acid deficiency. The prevalence of anemia in pregnancy is very high $45 \%$ to $67 \%$ in developing countries. ${ }^{[21]}$ Studies show that educated women are less likely to have anemia than uneducated educated pregnant women who have better income and nutritious food better medical facilities. A study conducted in Ethiopia also shows that anemia is more common in educated pregnant women. ${ }^{[21]}$

\section{Conclusion}

The causes of anemia are diverse. The most common cause is nutritional and iron deficiency follows by megaloblastic anemia. These can be prevented by periodical health checkups and Investigations'. So health agencies Govt. and NGOs have to focus on this issue especially in rural areas. In elderly people chronic renal failure and homological and GI Malign ayes are common. In India still, the common cause of anemia is nutrition and pregnancy is the next common cause.

\section{References}

1. Chaparro CM, Suchdev PS. Anemia epidemiology, pathophysiology, and etiology in low- and middle-income countries. Ann N Y Acad Sci. 2019;1450(1):15-31. Available from: https: //dx.doi.org/10.1111/nyas.14092.

2. Shavelle RM, MacKenzie R, Paculdo DR. Anemia and mortality in older persons: does the type of anemia affect survival? Int J Hematol. 2012;95(3):248-256. Available from: https://dx.doi.org/10.1007/s12185-012-1007-z.

3. Aslinia F, Mazza JJ, Yale SH. Megaloblastic Anemia and Other Causes of Macrocytosis. Clin Med Res. 2006;4(3):236-241. Available from: https://dx.doi.org/10.3121/cmr.4.3.236.

4. Fisher JW, Koury S, Ducey T, Mendel S. Erythropoietin production by interstitial cells of hypoxic monkey kidneys. $\mathrm{Br}$ J Haematol. 1996;95(1):27-32. Available from: https://dx.doi. org/10.1046/j.1365-2141.1996.d01-1864.x.

5. Molloy AM, Kirke PN, Brody LC, Scott JM, Mills JL. Effects of folate and vitamin B12 deficiencies during pregnancy on fetal, infant, and child development. Food Nutr Bull. 2008;29(2 Suppl):S101-11. Available from: https://dx.doi.org/10.1177/ 15648265080292 S114.

6. Maamar M, Tazi-Mezalek Z, Harmouche H, Ammouri W, Zahlane M, Adnaoui M, et al. Neurological manifestations of vitamin B12 deficiency: a retrospective study of 26 cases. Rev Med Interne. 2006;27(6):442-7. Available from: https: //dx.doi.org/10.1016/j.revmed.2006.01.012.

7. Linder MC. Mobilization of Stored Iron in Mammals: A Review. Nutrients. 2013;5(10):4022-4050. Available from: https://dx.doi.org/10.3390/nu5104022.

8. Manning JM. Normal and abnormal protein submit interaction in hemoglobin. J Biol Chem. 1998;273(31):19359-62-19352. Available from: https://doi.org/10.1074/jbc.273.31.19359.

9. Johnson-Wimbley TD, Graham DY. Diagnosis and management of iron deficiency anemia in the 21 st century. Therap Adv Gastroenterol. 2011;4(3):177-184. Available from: https: //dx.doi.org/10.1177/1756283X11398736.

10. Patel KV. Epidemiology of Anemia in Older Adults. Semin Hematol. 2008;45(4):210-217. Available from: https://dx.doi. org/10.1053/j.seminhematol.2008.06.006. 
11. Tettalante M, Luca V. Gandini F prevalence, incidence, and types of Mild Anemia in the elderly. The Health and Anemia "Population-based study. vol. 95; 2010. Available from: https: //doi.org/10.3324/haematol.2010.023101.

12. Nguyen PH, Scott S, Avula R, Tran LM, Menon P. Trends and drivers of change in the prevalence of anaemia among 1 million women and children in India, 2006 to 2016. BMJ Glob Health. 2018;3(5):e001010. Available from: https://dx.doi.org/ 10.1136/bmjgh-2018-001010.

13. Narayanan M, Reddy KM, Marsicano E. Peptic Ulcer Disease and Helicobacter pylori infection. Mo Med. 2018;115(3):219224.

14. Boone S, Powers JM, Goodgame B, Peacock WF. Identification and Management of Iron Deficiency Anemia in the Emergency Department. J Emerg Med. 2019;57(5):637-645. Available from: https://dx.doi.org/10.1016/j.jemermed.2019.08.052.

15. Nagao T, Hirokawa M. Diagnosis and treatment of macrocytic anemias in adults. J Gen Fam Med. 2017;18(5):200-204. Available from: https://dx.doi.org/10.1002/jgf2.31.

16. Dignass A, Farrag K, Stein J. Limitations of Serum Ferritin in Diagnosing Iron Deficiency in Inflammatory Conditions. Int J Chronic Dis. 2018;2018:9394060. Available from: https: //dx.doi.org/10.1155/2018/9394060.

17. Milman N. Anemia - still a Major health problem in many parts of the world. Ann Hematol. 2011;90(4):369-377. Available from: https://doi.org/10.1007/s00277-010-1144-5.
18. Melman N Anemia - still a major health problem in many parts of the world. Ann Hematol. 2011;90:369-369.

19. Gardner RV. Sickle Cell Disease: Advances in Treatment. Ochsner J. 2018;18(4):377-389. Available from: https://dx.doi. org/10.31486/toj.18.0076.

20. O'Leary F, Samman S. Vitamin B12 in Health and Disease. Nutrients. 2010;2(3):299-316. Available from: https://dx.doi. org/10.3390/nu2030299.

21. Haidar J. Prevalence of Anaemia, Deficiencies of Iron and Folic Acid and Their Determinants in Ethiopian Women. J Health Popul Nutr. 2010;28(4):359-368. Available from: https: //dx.doi.org/10.3329/jhpn.v28i4.6042.

Copyright: (C) the author(s), 2020. It is an open-access article distributed under the terms of the Creative Commons Attribution License (CC BY 4.0), which permits authors to retain ownership of the copyright for their content, and allow anyone to download, reuse, reprint, modify, distribute and/or copy the content as long as the original authors and source are cited.

How to cite this article: Ardhapuskar S, Rammulu R. An Analytical Study on Anemia in Rural Population. Acad. J Med. 2020;3(2):28-33.

DOI: dx.doi.org/10.47008/ajm.2020.3.2.7

Source of Support: Nil, Conflict of Interest: None declared. 